\title{
PELATIHAN PERTOLONGAN PERTAMA SEARCH AND RESCUE (PP- SAR) AIR NASIONAL KORPS SUKARELA PALANG MERAH INDONESIA DAN RELAWAN PERGURUAN TINGGI SE-INDONESIA
}

\author{
Saddam $^{1^{*}}$, Yudhi Lestanata ${ }^{2}$, Isnaini ${ }^{3}$ Ihsan $^{4}$, Muhamad Saoki ${ }^{5}$, \\ M. Ulfatul Akbar Jafar ${ }^{6}$ \\ 1,3 Pendidikan Pancasila dan Kewarganegaraan, Universitas Muhammadiyah Mataram, Indonesia \\ ${ }^{2,6}$ Administrasi Publik, Universitas Muhammadiyah Mataram, Indonesia \\ ${ }^{4}$ Pendidikan Pancasila dan Kewarganegaraan, Universitas Muhammadiyah Sorong, Indonesia \\ ${ }^{5}$ Sistem Informasi, Universitas Nahdlatul Ulama Mataram, Indonesia \\ 1'saddamalbimawi1@gmail.com, ${ }^{2}$ yudhieselotho@yahoo.co.id, ${ }^{3}$ isnainihtn.mh8@gmail.com, \\ 4saokien88@gmail.com, ${ }^{5}$ ahmadmihsan0@gmail.com, ${ }^{6}$ akbarsanggar09@gmail.com
}

\begin{abstract}
ABSTRAK
Abstrak: Pelatihan Pertolongan Pertama SAR Air Nasional KSR-PMI dan Relawan Perguruan Tinggi se-Indonesia berdampak baik bagi mahasiswa. Kegiatan ini guna meningkatkan skill tanggap darurat bencana air/laut, wahana habituasi bidang kepalangmerahan, kreatifitas dan profesionalisme dalam upaya pelayanan kepada masyarakat, menyamakan persepsi KSR dan relawan perguruan tinggi se-Indonesia. Pelatihan ini urgen mengingat resiko kebencanaan di Indonesia makin tinggi, bencana dominan sepuluh tahun terakhir diantaranya banjir, tanah longsor, gelombang abrasi, puting beliung, kekeringan, kebakaran, tsunami, gempa bumi, dan letusan gunung api. Pelatihan merupakan salah satu solusi penanganan kebencanaan. Pelatihan ini berlangsung sepuluh hari tahapannya; teori dalam kelas, praktek lapangan, simulasi, aksi sosial, dan kunjungan wisata. Teori, praktik, dan simulasi didatangkan ahli-ahli bindang kepalangmerahan, penanggulangan bencana, dan akademisi. Ahli-alhi tersebut dari PMI Provinsi NTB dan Kota Mataram, BASARNAS Lombok Barat, dan Dosen. Materi yang dibahas manajemen kepemimpinan organisasi mahasiswa, manajemen pelatihan, radio komunikasi dan pengenalan BASARNAS, manajemen penanggulangan bencana, pertolongan pertama, pengantar SAR air, pedoman SAR air dan metode SAR air, deven and rilis, dan akses korban dalam air. Simulasi dilaksanakan di Pantai Gading dan kolam renang, bhakti sosial berlangsung di Gunung Jae. Keberhasilan pelatihan ini terlihat dari semangat, antusias, dan hasil simulasi. Peserta sudah memahami teknik dan motode pelaksanaan PP-SAR air dalam penanggulangan bencana.
\end{abstract}

Kata Kunci: KSR-PMI; Relawan; dan Pertolongan Pertama SAR Air.

\begin{abstract}
First-aid training of national Water SAR (KSR) and Indonesian college volunteers have a good impact on students. This activity is to improve the emergency response skills of water/sea disasters, the field of Habitat habituation, creativity, and professionalism in the service effort to the community, equate the perception of KSR and college volunteers in Indonesia. This training urgent considering the risk of disaster in Indonesia is higher, the dominant disasters of the last ten years include floods, landslides, abrasion waves, nipples, droughts, fires, tsunamis, earthquakes, and volcanic eruptions. Training is one of disaster management solutions. The training lasted ten days; Theory in class, field practice, simulation, social action, and tourist excursions. Theory, practice, and simulation come from the experts in the head, disaster management, and academics. The experts are from NTB provincial PMI and Mataram City, BASARNAS West Lombok, and lecturer. The materials covered by Student organization leadership Management, training management, radio communication and introduction of BASARNAS, disaster management, first aid, Introduction to water SAR, water SAR guidelines and water SAR methods, Deven and release, and access to victims in the water. Simulation is carried out in Ivory Coast and swimming pool, social bhakti takes place at Mount Jae. The success of this training was seen from passion, enthusiasm, and simulated results. Participants already understand the technique and methods of the implementation of PP-SAR water in disaster management.

Keywords: KSR-PMI; Volunteer; dan Firt Aid Water Search And Rescue.
\end{abstract}




\section{A. LATAR BELAKANG}

Perbandingan luas lautan dan daratan di dunia mencapai kurang lebih 70 berbanding 30. Menjadi tantangan khusus bagi Negara-negara di belahan dunia yang memiliki kepentingan laut untuk memajukan maritimnya dan mengantispasi segala kemungkinan wilayah perairan. Secara geografis Indonesia merupakan negara kepulauan dengan dua pertiga luas lautan lebih besar daripada daratan. Sehingga Indonesia dikatakan sebagai negara meritim, di mana wilayah perairannya lebih luas dari pada daratan. Hal tersebut terlihat dari adanya garis pantai dihampir setiap pulau, menjadikan Indonesia menempati urutan kedua sebagai Negara dengan garis pantai terpanjang di dunia setelah Negara Kanada.

Indonesia memiliki 17.499 pulau, dengan luas perairan lautnya mencapai 5,9 juta $\mathrm{km} 2$ dan garis pantai sepanjang $81.000 \mathrm{~km}^{2}$, kondisi tersebut menjadikan Indonesia sebagai center of gravity kawasan Asia Pasifik (Marsetio, 2013). Kriteria Badan Meteorologi Klimatologi dan Geofisika (BMKG) dalam menentukan awal musim hujan dan awal musim kemarau memerlukan waktu sebulan untuk memastikan masuknya musim hujan dan musim kemarau (Giarno, Dupe, \& Mustofa, 2012). Indonesia terletak diantara dua benua dan dua samudera. Negara kepulauan antara yang laut sebagai pemisah antara pulau-pulaunya. Indonesia memiliki dua musim, yaitu musim kemarau dan musim hujan.

Indonesia merupakan wilayah yang rawan bencana, dilatarbelakangi suatu realitas bahwa Indonesia dikelilingi tiga lempeng tektonik aktif, deretan gunungapi aktif bagian dari ring of fire dan letak geografis yang dilewati garis khatulistiwa (Tangguh, n.d.). Resiko bencana di Indonesia makin tinggi terutama banjir. Indonesia menjadi salah satu negara langganan bencana terutama banjir. Seperti yang tertera pada Gambar 1. bahwa sepanjang tahun 2018 tingkat kejadian bencana tergolong tinggi, hal tersebut terlihat dari rentetan bencana dari tahun 2010-2019. .

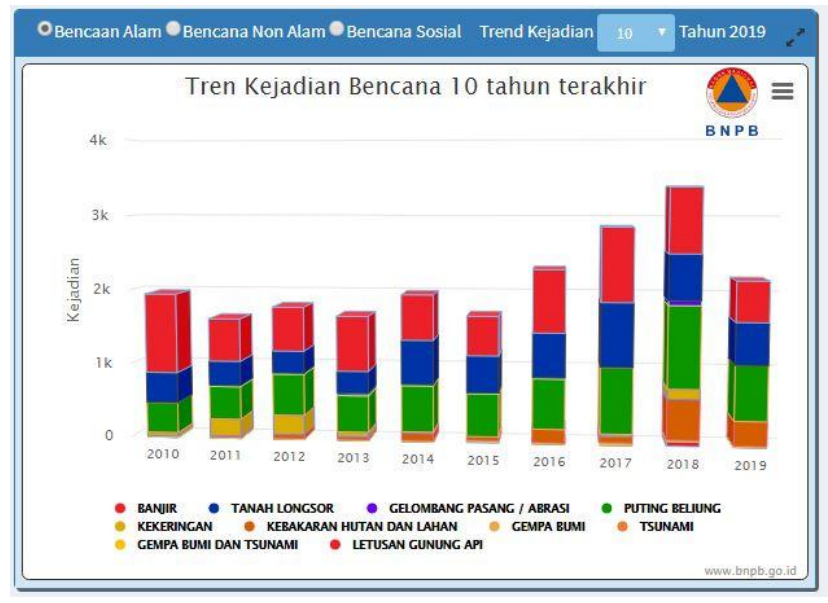

Gambar I. Bencana 10 Tahun Terakhir di Indonesia (Bencana, 2017).

Pada Gambar 1. di atas menunjukkan bencana yang sering terjadi dalam sepuluh tahun terakhir adalah banjir, tanah longsor, gelombang 
pasang/abrasi, putting beliung, kekeringan, kebakaran hutan dan lahan, tsunami, gempa bumi dan tsunami, dan letusan gunung api. Berdasarkan data terbaru bencana banjir di Indonesia sepanjang tahun 2019 sangat tinggi dengan jumlah kejadian 549 dengan korban jiwa yang meninggal dan hilang 325 dan luka-luka mencapai 1,052, serta jumlah yang terdampak dan mengungsi 979,499 (Bencana, 2017). Banjir menempati posisi pertama sebagai bencana yang terjadi di setiap tahunnya (Akbar, Abedi, Handayani, \& Eka, 2017). Banjir adalah meluapnya aliran sungai akibat air melebihi kapasitas tampungan sungai sehingga meluap dan mengenangi dataran atau daerah yang lebih rendah sekitarnya (Yulaelawati, 2008). Pada dasarnya banjir merupakan fenomena alam biasa yang sering terjadi hampir diseluruh Negara-negara di dunia termasuk Indonesia. Bencana banjir, tsunami dan gelombang pasang menjadi sorotan menarik mengingat $70 \%$ wilayah Indonesia merupakan wilayah perairan. Hal ini tentu saja menuntut masyarakat Indonesia untuk siaga terhadap bencara banjir, tsunami, dan gelombang pasang.

Bencana secara langsung menimbulkan kerugian di berbagai aspek kehidupan masyarakat. Kerugian yang dirasakan berupa kerugian materil dan moril. Kerugian moril yang timbul diantaranya kondisi mental menurun atau terganggu dikarenakan seseorang kehilangan keluarga dan harta benda akibat bencana tersebut. Badan Nasional Penanggulangan Bencana (BNPB) adalah salah satu badan yang ada di Indonesia yang bertugas membantu Presiden Republik Indonesia untuk mengkoordinasikan perencanaan dan pelaksanaan kegiatan penanganan bencana dan kedaruratan secara terpadu, serta melaksanakan penanganan bencana dan kedaruratan mulai dari sebelum, pada saat, dan setelah terjadi bencana yang meliputi pencegahan, kesiapsiagaan, penanganan darurat, dan pemulihan (Indonesia, 2008). Salah satu daerah yang terdampak banjir bandang khususnya di akhir tahun 2016 adalah Kabupaten Bima dan Kota Bima Provinsi Nusa Tenggara Barat. Merupakan banjir bandang terbesar yang pernah terjadi di daerah tersebut, kerugian secara material yang sangat signifikan. Selain banjir bandang banyak kapal-kapal di berbagai daerah yang mengalami kecelakaan saat melintasi laut.

Berdasarkan uraian di atas urgen untuk mempersiapkan relawanrelawan muda yang berkualitas dan terampil di bidang kepalangmerahan guna menghadapi berbagai kemungkinan bencana kedepannya. Hal ini sebagai upaya kesiapsiagaan, masyarakat perlu mentor yang akan melatih keterampilan ilmu dalam menangani bencana. Bencana merupakan fenomena yang tidak bisa dihilangkan melainkan harus dihadapi dan diantisipasi. Untuk menghadapinya sudah seharusnya masyarakat bergerak dibidang kemanusiaan guna dapat membantu pemerintah melakukan kesiapsiagaan. Terutama menyiapkan sumber daya manusianya, sehingga di saat kondisi dan situasi bencana dapat memberi bantuan atau pertolongan terhadap diri sendiri dan orang lain. Dengan 
berbagai bencana yang sering terjadi maka sangat penting menyiapkan relawan-relawan sebagai sumber daya manusia terlatih dalam menangani kebencanaan, baik relawan yang dibentuk pemerintah maupun relawan yang berdiri sendiri.

Melihat, menelaah, dan mencermati kondisi tersebut unit Kegiatan Mahasiswa Korps Sukarela Palang Merah Indonesia (KSR-PMI) Unit Universitas Muhammadiyah Mataram (UMMat) degan tekad yang bulat mengadakan Pelatihan Pertolongan Pertama Search And Rescue (SAR) Air Nasional Korps Sukarela Palang Merah Indonesia dan Relawan Perguruan Tinggi se-Indonesia yang di singkat "PP-SAR Air". Dasar pelaksanaan kegiatan ini yaitu Sapta Prinsip Palang Merah dan Bulan Sabit Merah Internasional, Angaran Dasar dan Anggaran Rumah Tangga PMI dan KSRPMI Unit UMMat, Undang-undang No. 2 Tahun 1998 tentang Pendidikan Nasional, Catur Dharma Perguruan Tinggi Muhammadiyah, Keputusan MENDIKBUD No. 155/1998 tentang pedoman organisaasi Kemahasiswaan di perguruan Tinggi, Garis-garis Besar Program Kegiatan (GBPK) KSRPMI Unit UMMAT, Program Kerja KSR-PMI Unit UMMat, dan hasil rapat Pengurus KSR-PMI Unit UMMat pada tanggal 27 Januari 2018.

\section{B. METODE PELAKSANAAN}

Kegiatan Pelatihan PP-SAR Air Nasional KSR-PMI dan Relawan Perguruan Tinggi se-Indonesia ini diselenggarakan oleh KSR-PMI unit UMMat berkedudukan di Pulau Lombok Provinsi Nusa Tenggara Barat. Kegiatan dilaksanakan sebagai usaha pencegahan dalam mengantisipasi resiko ketika bencana, sebagai usaha pesan moral kepada penerus bangsa akan pentingnya langkah antisipasi kebencanaan berdasarkan kondisi wilayah. Selaian itu, kegiatan ini jugasebagai upaya membantu PMI dan Pemerintah dalam usaha memberikan keterampilan atau skill kepada relawan khususnya dalam bidang manajemen tanggap darurat bencana di air, meningkatkan keterampilan, kreatifitas dan profesionalisme dalam upaya memberi pelayanan kepada masyarakat, menyamakan persepsi anggota KSR Perguruan Tinggi dan relawan Perguruan Tinggi se-Indonesia dalam pertolongan di air / laut, sebagai wahana pendidikan dan latihan guna mengembangkan ilmu pengetahuan dalam bidang kepalang merahan, khususnya dalam pertolongan di air / laut, dan meningkatkan kerjasama dan silaturahmi serta rasa kebersamaan dan kesatuan yang solid antar KSR-PMI perguruan tinggi se-Indonesia.

Adapun metode pelaksanan Pelatihan Pertolongan Pertama Search And Rescue (SAR) Air Nasional Korps Sukarela Palang Merah Indonesia dan Relawan Perguruan Tinggi se-Indonesia dilaksanakan dengan baik melalui tahapan berikut. 


\section{Analisis Awal}

Tahap analisis awal ini ditandai dengan meninjau permasalahan sehingga pelatihan ini urgen dilaksanakan. Adapun masalah yang menjadi dasar pelaksanaan adalah sebagai berikut:

a. Indonesia menjadi salah satu negara langganan bencana terutama banjir;

b. sepanjang tahun 2018 merupakan tahun di mana tingkat kejadian bencana sangat tinggi di Indonesia dari 10 tahun terakhir;

c. bencana yang sering terjadi dalam 10 terakhir diantaranya banjir, tanah longsor, gelombang pasang/abrasi, putting beliung, kekeringan, kebakaran hutan dan lahan, tsunami, gempa bumi dan tsunami, dan letusan gunung api;

d. bencana tidak bisa dihilangkan melainkan harus dihadapi dan diantisipasi, sehingga kesiapsiagaan penting;

e. pentingnya menyiapkan sumber daya manusia danmasyarakat yang memiliki skill penanganan bencana, sehingga di saat kondisi dan situasi bencana dapat memberi bantuan atau pertolongan terhadap diri sendiri dan orang lain;

f. dengan berbagai bencana yang sering terjadi maka sangat penting menyiapkan relawan-relawan sebagai sumber daya manusia yang terlatih tentang kebencanaan, baik relawan yang dibentuk pemerintah maupun relawan yang berdiri sendiri.

\section{Proses Persiapan}

Tahap persiapan dari PP-SAR Air Nasional KSR-PMI dan Relawan Perguruan Tinggi se-Indonesia yang diselenggarakan oleh KSR-PMI unit UMMat melalui proses persiapan dan dirancangan antara tim pelaksana beserta mitra. Adapun proses persiapannya adalah sebagai berikut:

a. peninjauan rencana pelaksanaan program PP-SAR Air, diantaranya; (1) rapat koordinasi pengurus, (2) pembentukan panitia penyelenggara. (3) menyiapkan proposal kegiatan, suratmenyurat, petunjuk pelaksana dan petunjuk teknis (JuklakJuknis), dan pomosi kegiatan;

b. persiapan perlengkapan kegiatan;

c. persiapan tampat pelaksanaan kegiatan;

d. penginapan peserta dan panitia.

\section{Proses Pelaksanaan}

Tahapan terakhir dari pelaksanan Pelatihan Pertolongan Pertama Search And Rescue (SAR) Air Nasional Korps Sukarela Palang Merah Indonesia dan Relawan Perguruan Tinggi se-Indonesia adalah proses pelaksanaan. Kegiatan ini dilaksanakan dalam beberapa tahapan berupa pelatihan dan non-pelatihan, terdiri dari tahapan berikut.

1. Teori di dalam Kelas.

2. Praktek Lapangan (Kolam Renang dan Laut). 
3. Simulasi.

4. Aksi Sosial.

5. Kunjungan Wisata.

\section{HASIL DAN PEMBAHASAN}

Korps Sukarela Palang Merah Indonesia unit UMMat merupakan unit penyelenggara "Nasional Firt Aid Water Search And Rescue Korps Sukarela Palang Merah Indonesia dan Relawan Perguruan Tinggi se-Indonesia". Tema kegiatan yaitu "Habituasi Dedikasi Relawan yang Berkarakter Melalui Nasional Firt Aid Water Search And Rescue". Peserta pelaksanaan pelatihan Pertolongan Pertama (PP) Search And Rescue (SAR) Air Nasional Korps Sukarela Perguruan Tinggi dan Relawan Perguruan Tinggi seIndonesia adalah mahasiswa dari anggota atau pengurus KSR Perguruan Tinggi dan Relawan Perguruan Tinggi se-Indonesia.

Kegiatan Pelatihan PP-SAR AIR Nasional I KSR-PMI dan Relawan Unit Perguruan Tinggi se-Indonesia dilaksanakan dari tanggal 02 s/d 10 Mei 2018 yang bertempat di kampus UMMat, Pantai Gading, dan Gunung Jae Lombok Barat, Nusa Tenggara Barat. Kegiatan PP-SAR Air Nasional ini diklasifikasikan dalam dua bentuk yakni kegiatan inti dan kegiatan tambahan. Kegiatan inti dalam pelatihan ini berupa materi ruangan, simulasi lapangan/praktik dan bakti sosial. Sedangkan kegiatan tambahan berupa penyambutan, rekreasi/karya wisata, karnaval, dan malam puncak milad KSR-PMI Unit UMMat.

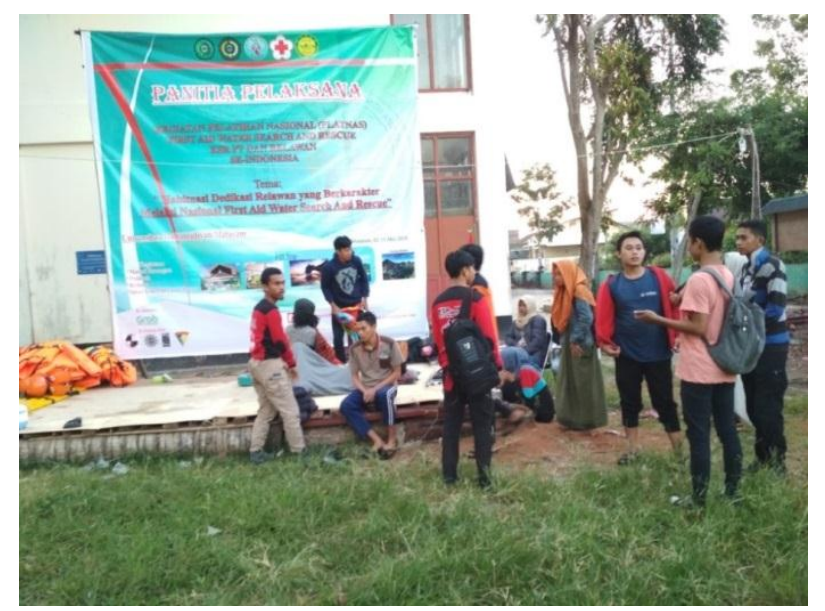

Gambar 2. Persiapan Pembukaan Pelatihan PP-SAR AIR Nasional KSR dan Relawan Unit Perguruan Tinggi se-Indonesia.

Pada gambar 2. di atas menunjukkan panitia penyelenggara kegiatan PP-SAR AIR Nasional menyiapkan panggung. Panggung tersebut akan digunakan pada acara pembukaan dan malam puncak milad KSR-PMI Unit UMMat. Kegiatan PP-SAR AIR Nasional ini dilaksanakan di 1) Kampus Universitas Muhammadiyah Mataram Jalan K.H. Ahmad Dahlan Nomor 1 Pagesangan Kota Mataram. 2) Pantai Gading Jalan Lingkar Selatan Jempong Baru Kota Mataram. 3) Kolam Renang Mayura di Jalan Taman 
Mayura Cakranegara Selatan Baru, Kota Mataram. Dan 4) Gunung Jae Desa Sedau Lombok Barat).

Pemateri kegiatan Pelatihan Nasional First Aid Water Search And Rescue adalah dari lembaga terkait dibidang kebencanaan, lembaga yang menangani SAR nasional, dan praktisi dari kalangan akademisi. Pembicara atau nara sumber adalah orang atau kelompok yang ditunjuk oleh panitia pelaksana untuk memandu, menyampaikan dan memberikan materi PPSAR Air Nasional yang diselenggarakan kepada peserta baik di ruangan maupun di lapangan. Diantara pemateri dalam kegiatan ini adalah sebagai berikut.

1) Badan Search And Rescue Nasional (BASARNAS) Provinsi NTB,

2) Palang Merah Indonesia Provinsi NTB, dan

3) Dosen Universitas Muhammadiyah Mataram.

Kegiatan ini dilaksanakan dalam beberapa tahapan berupa pelatihan dan non-pelatihan. Tahapan pelatihan dan non-pelatihan pelaksanan Pelatihan Pertolongan Pertama Search And Rescue (SAR) Air Nasional Korps Sukarela Palang Merah Indonesia dan Relawan Perguruan Tinggi seIndonesia adalah sebagai berikut.

\section{Teori di dalam Kelas}

Kegiatan ruangan dilaksanakan di Auditorium kampus UMMat dengan ketentuan-kententuan sebagai berikut.

A. Pemberian materi pada Pelatihan Pertolongan Pertama Nasional First Aid Water Search And Rescue KSR-PMI dan Relawan Perguruan Tinggi se-Indonesia dengan rincian materi sebagai berikut.

1) Manajemen Kepemimpinan Organisasi Mahasiswa

Manajemen kepemimpinan organisasi mahasiwa menjadi salah satu materi yang wajib disampaikan. Materi ini terkait dengan cara mengatur, mengelola, dan mengembangkan organisasi kemahasiswaan, terutama dalam mengorganisasikan pengurus dan anggota organisasi serta dalam melaksanakan kegiatan. Materi ini disampaikan pada hari kamis tanggal 3 Mei 2018 oleh akademisi dosen UMMat. Materi diberikan 2 sks bertempat di Aula Rektorat UMMat.

Manajemen Organisasi merupakan makna yang tidak dapat dipisahkan dari kata manajemen dan organisasi. Manajemen berarti proses perencanaan, pengorganisasian, memimpin dan mengarahkan sesuatu yang tergabung di dalamnya. Organisasi sendiri bermakna sekumpulan individu yang berkerja sama untuk mencapai tujuan bersama. Dengan dekimian, manajemen organisasi proses perencanaan, pengorganisasian, memimpin dan mengarahkan sumber daya dalam suatu perkumpulan atau organisasi untuk mencapai tujuan bersama. Di dalam organisasi terdapat Visi dan Misi, untuk mencapainya maka dibutuhkan 
manajemen organisasi sebagai proses lanjutan dalam menentukan strategi pencapaian. Tujuannya untuk memberikan rasa aman bagi semua yang tergabung dalam organisasi, sehingga kinerja anggota untuk melangsungkan organisasi melalui program-program bisa lebih efektif dan terjalin koordinasi satu sama lain.

2) Menejemen Pelatihan

Manajemen pelatihan mencakup teknis pelaksanaan kegiatan pelatihan. Manajemen pelatihan yang dilatih baik manajeman kegiatan yang sedang terlaksana maupun kegiatankegiatan selanjutnya yang akan diadakan. Materi disampaikan pada hari kamis tanggal 3 Mei 2018 oleh pihak PMI Kota Mataram. Materi terlaksana untuk waktu 2 sks bertempat di Aula Rektorat UMMat.

Manajemen Pelatihan merupakan makna yang digabungkan dari kata manajemen dan pelatihan. Pelatihan bermakna proses integrasi nilai berupa pengetahuan dan keterampilan teknis jangka pendek pada anggota pelatihan dengan prosedur sistematis dan terorganisir. Sedangkan manajemen berarti proses perencanaan, pengorganisasian, memimpin dan mengarahkan sesuatu yang tergabung di dalamnya. Dengan demikian, dapat dikatakan bahwa manajemen pelatihan berarti proses perencanaan, pengorganisasian, mengarahkan kegiatan pelatihan yang mencakup perencanaan, pengorganisasian, pelaksanaan dan evaluasinya.

3) Radio Komunikasi dan Pengenalan BASARNAS

Seiring perkembangan teknologi, berbagai perubahan telah terjadi, termasuk dibidang teknologi komunikasi. Demikian halnya dengan pihak BASARNAS mulai memanfaatkan teknologi dalam komunikasi saat meangani bencana. BASARNAS memanfaatkan gelombang radio sebagai sarana komunikasi dan pengenalan, gelombang radio dimanfaatkn yang memungkinkan komunikasi dapat dilakukan dalam berbagai situasi. Materi disampaikan pada hari kamis tanggal 3 Mei 2018 oleh pihak BASARNAS Kota Mataram. Materi terlaksana untuk waktu 2 sks bertempat di Aula Rektorat UMMat.

Menangani bencana perlu adanya panduan konsep komunikasi bencana dan teori perencanaan komunikasi. Badan Penanggulangan Bencana Kota Medan dalam menangani bencana melakukan perencanaan komunikasi yang sesuai peraturan untuk mencegah risiko bencana misalnya komunikasi yang tidak terputus dengan Badan Meteorologi, Klimatologi dan Geofisika (BMKG), mendirikan sekolah sungai, merekrut relawan setiap kelurahan serta mengadakan sosialiasi rutin di daerah rawan 
bencana (Zubaidi, 2018). Dengan ini, dalam menangani bencana harus disipkan panduan konsep komunikasi bencana dan prencanaan komunikasi saat penanganan bencana. Pada gambar 3. di bawah ini menunjukkan kumunikasi pengenalan BASARNAS dan persiapan tim untuk melakukan simulasi penanganan korban di laut.

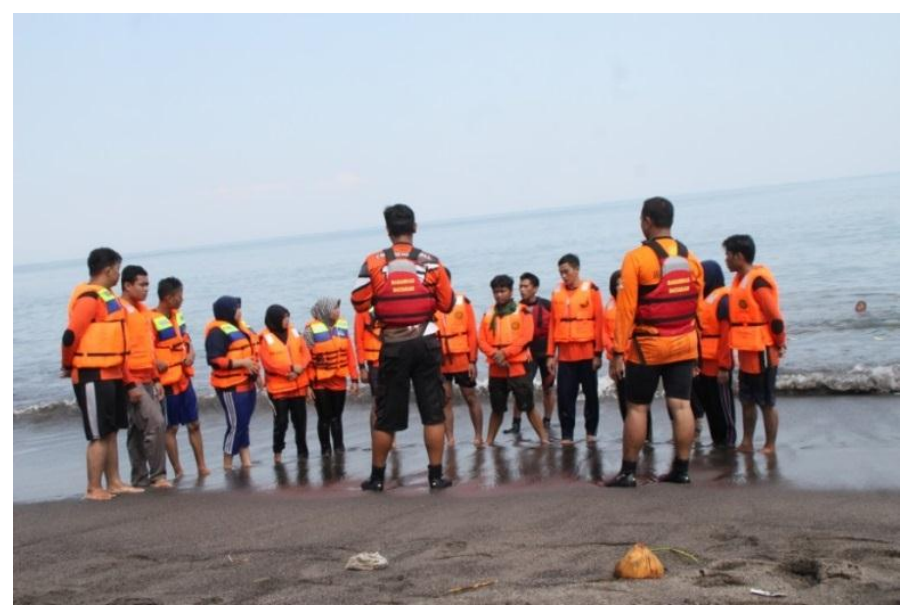

Gambar 3. Komunikasi Para Relawan dan Pengenalan BASARNAS di Lapangan.

4) Manajemen Penanggulangan Bencana

Resiko bencana di Indonesia makin tinggi, sehingga pertumbuhan kapasitas penanggulangan bencanapun harus terus berkembang. Pertumbuhan kapasitas penanggulangan bencana harus tetap dijaga dengan berbagai upaya, baik oleh pemerintah, masyarakat, organisasi masyarakat, pihak swasta, serta oleh mahasiwa. Strategi yang dilakukan pemerintah sejauh ini adalah internalisasi pengurangan risiko bencana. Hal ini dilakukan dalam kerangka pembangunan berkelanjutan di pusat dan daerah untuk penurunan tingkat kerentanan terhadap bencana, serta peningkatan kapasitas pemerintah, pemerintah daerah dan masyarakat dalam penanggulangan bencana. Sehingga sangat penting kiranya disiapkan sumber daya manusia yang bisa paham cara penanggulangan bencana. Dengan ini belajar dari pengalaman serta pentingnya praktik-praktik pengurangan risiko bencana dan penanggulangan bencana merupakan langkah kongkrit untuk memperkuat kesiapan masyarakat menangani bencana. Materi Manajemen Penanggulangan Bencana disampaikan pada hari Jum'at tanggal 4 Mei 2018 oleh pihak PMI Kota Mataram. Materi terlaksana untuk waktu 4 sks bertempat di Aula Rektorat UMMat.

5) Pertolongan Pertama

Pertolongan Pertama adalah memberikan penanganan awal segera kepada penderita yang membutuhkan pananganan medis 
dasar. Pertolongan Pertama merupakan pengembangan dari P3K atau Pertolongan Pertama Pada Kecelakaan. Hal ini diberikan dengan teknik dan cara-cara tertentu dan biasanya hanya bisa dilakukan oleh yang sudah memahami ataupun belum memahami teknik-tekniknya. Materi disampaikan pada hari Jum'at tanggal 4 Mei 2018 oleh pihak PMI. Materi terlaksana untuk waktu 4 sks bertempat di Aula Rektorat UMMat.

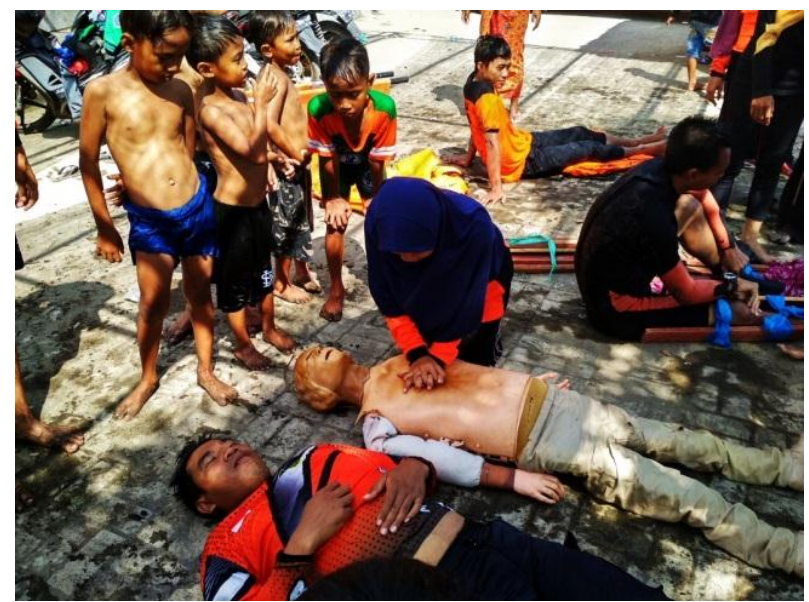

Gambar 4. Teknik Resusitasi Jantung Paru (RJP) atau Cardiopulmonary Resuscitation (CPR)

Pada gambar 4. di atas menunjukkan peserta pelatihan menangani korban tenggelam dengan Teknik Resusitasi Jantung Paru (RJP) atau Cardiopulmonary Resuscitation (CPR). Cardiopulmonary Resuscitation (CPR) adalah teknik menyelamatkan nyawa yang sangat berguna dalam banyak keadaan darurat, seperti serangan jantung atau hampir tenggelam, di mana pernapasan atau detak jantung seseorang telah berhenti(Ganthikumar, 2016). Kompresi dada sangat bisa membantu menyelamatkan nyawa siapapun yang membutuhkan, teknik ini lebih baik bagi korban daripada melakukan teknik lain. Teknik ini dapat mengirimkan oksigen yang cukup yang dibutuhkan otak dan organ vital guna mengembalikan kerja otak dan organ vitas sebelum obat definitif diberikan untuk mengembalikan irama normal jantung.

6) Pengantar SAR Air, Pedoman Sar Air dan Metode Sar Air

Materi Pengantar SAR Air disampaikan pada hari Sabtu tanggal 5 Mei 2018 oleh pihak BASARNAS. Materi terlaksana untuk waktu 4 sks bertempat di Aula Rektorat UMMat. Pedoman SAR Air disampaikan pada hari Sabtu tanggal 5 Mei 2018 oleh pihak BASARNAS. Materi terlaksana untuk waktu 4 sks bertempat di Aula Rektorat UMMat. Metode SAR Air disampaikan pada hari Minggu tanggal 6 Mei 2018 oleh pihak BASARNAS. Materi terlaksana untuk waktu 4 sks bertempat di 
Aula Rektorat UMMat. Materi pelatihan PP-SAR Air disampaikan dalam beberapa bentuk dan metode. yakni ceramah, diskusi, tanya jawab, dan simulasi di lapangan.

SAR Air merupakan kegiatan atau upaya mencari, menolong, dan menyelamatkan jiwa manusia yang didetksi hilang dan/atau dikhawatirkan hilang dalam menghadapi kondisi bahaya atau musibah. SAR merupakan istilah yang telah digunakan secara internasional sehingga tidak asing bagi orang di belahan dunia manapun termasuk Indonesia. Operasi SAR biasanya dilaksanakan di medan yang terkategori berat baik diperdesaan maupun perkotaan. Operasi ini harus dilakukan oleh yang memiliki keterampilan dan teknik penanganannya, sehingga tidak membahayakn diri sendiri, tim, dan korban. Operasi SAR dilaksanakan saat terjadi bencana/musibah penerbangan, laut, gedung runtuh, kebakaran, dan kecelakaan berat lainnya. Untuk bencana alam, operasi SAR menjadi rangkaian dari siklus penanganan kedaruratan penanggulannya. Siklus penanganannya terdiri dari; 1) mitigasi (pencegahan), 2) preparedness (kesiagaan), 3) response (tanggap darurat), 4) recovery (pemulihan). Hal ini merupakan bagian dari tindakan tanggap darurat.

\section{Praktek Lapangan}

Praktik lapangan dilaksanakan pada hari senin tanggal 7 Mei 2018 bertempat di Pantai Gading Jalan Lingkar Selatan Jempong Baru Kota Mataram, dan Kolam Renang Mayura di Jalan Taman Mayura Cakranegara Selatan Baru Kota Mataram. Praktik dilaksanakan dengan peralatan lengkap, dan dipandu oleh BASARNAS dengan alokasi waktu 6 sks. Sedangkan untuk praktik berupa bakti sosial dilaksanakan pada hari selasa tanggal 8 Mei 2018 bertempat di Gunung Jae.

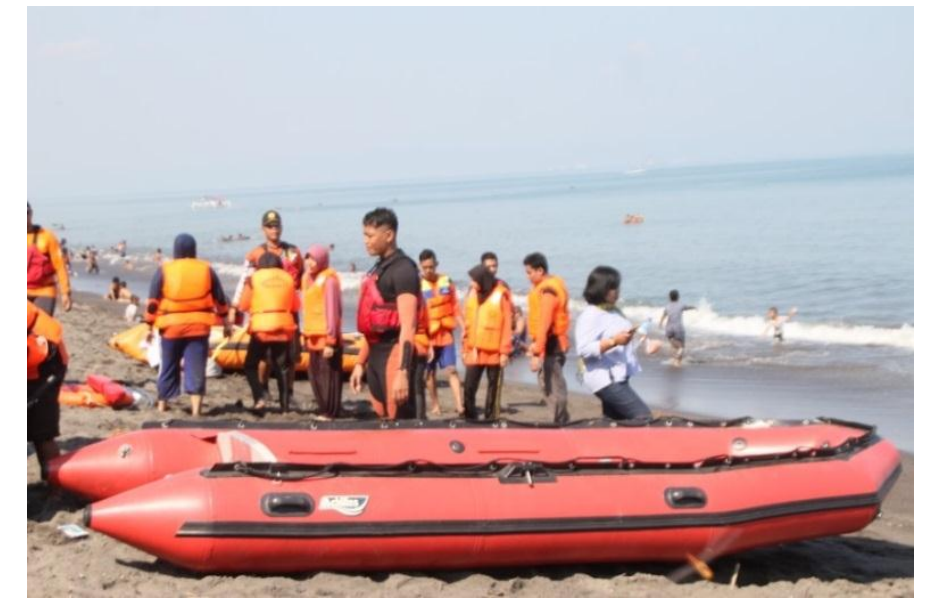

Gambar 5. Perahu untuk Akses Korban dalam Air

Pada gambar 5. di atas menunjukkan persiapan praktik lapangan akses korban dalam air menggunakan perahu. Praktik dilaksanakan di Pantai Gading Jalan Lingkar Selatan Jempong Baru Kota Mataram. 
Praktik Search And Rescue, Pertolongan Pertama dan Survival lapangan terlaksana di Pantai Gading dan Kolam Renang Mayura. Di Gunung Jae lombok Barat untuk praktik Aksi Sosial. Sedangka Aksi Sosial terlaksana di Gunung Jae Lomok Barat, kegiatan ini berlangsung sehari bersama masyararakat disekitar Gunung Jae. Tempat ini juga biasa digunakan KSR-PMI Unit UMMat untuk DIKLATSAR (Pendidikan dan Pelatihan Dasar) anggota baru.

\section{Simulasi}

Simulasi berlangsung untuk penguatan materi ruangan dan praktik yang telah diperoleh peserta pelatihan selama tujuh hari. Simulasi yang dilakukan adalah cara akses korban dalam air dan pemberian pertolongan pertama, tidak terlepas juga manajemen penanggulangan bencana, dan komunikasi para relawan. Pada gambar 6. di bawah ini menunjukkan peserta malakukan simulasi akses korban dalam air menggunakan perahu. Simulasi dilaksanakan di laut wilayah Kota Mataram.

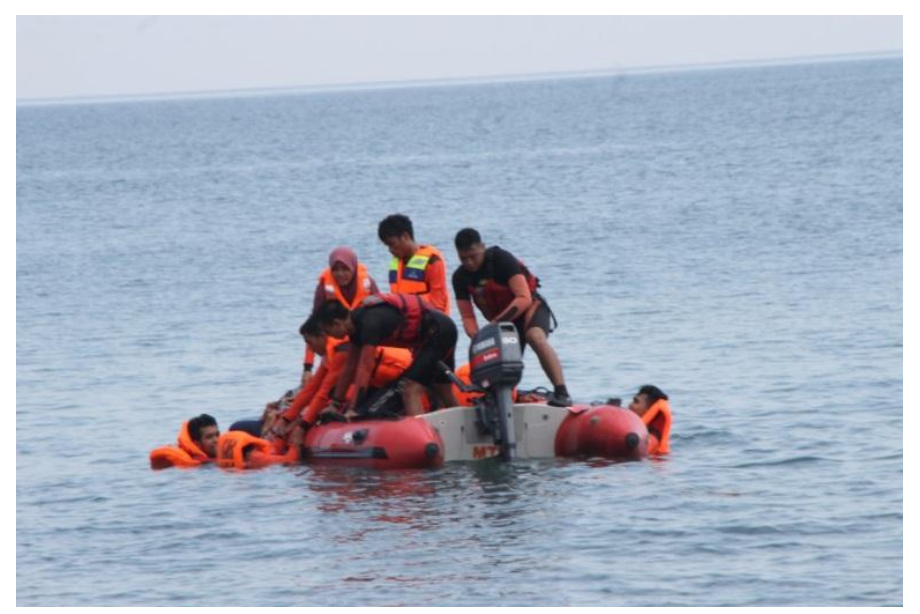

Gambar 6. Teknik Mengevakuasi Korban di Atas Perahu

Water Rescue merupakan kegiatan pertolongan atau penyelamatan dengan cara memindahkan korban dari perairan (kolam, sungai, dan laut) menuju daratan menggunakan media atau secara langsung dengan pengamanan. Ada beberapa hal yang harus dilakukan sebelum menolong korban di dalam perairan. Pertama, harus melakukan pengamatan terlebih dahulu. Diantaranya mengamati kondisi air, mengenali tepi/pinggiran air, mengetahui/mengira kedalaman air, dan memprhatikan kuatnya arus air. Jika akan melakukan pemotongan atau menyeberangi air jangan berlawanan 90 derajat, ikutilah arus air.

Untuk korban tenggelam ada beberapa tehnik dalam memberi pertolongan, yakni: Pertama Raih; raihlah korban dengan tangan jika belum terlalu jauh dan dengan mengunakan alat tertentu jika korban sudah cukup jauh. Upayakan menggunakan/memakai alat yang terapung. Kedua Lempar; lempari korban dengan benda terapung tertentu di sekitarnya yang dapat dijangkau oleh korban, lalu tarik 
korban pelan-pelan. Setelah itu angkatlah korban keluar dari air. Ketiga Dayung; dekati korban dengan menggunakan perahu, kemudian gapai korban dan angkatlah korban dari dalam air ke atas perahu yang digunakan untuk menolong korban. Keempat Renang; berenanglah untuk mendekati korban, raih dan tarik korban dari belakang dan tenangkan. Kemudian bawa korban keluar dari air menuju daratan atau tempat yang aman.

Teknik lain adalah dengan cara-cara berikut.

a) Reach; yakni teknik pertolongan yang dilakukan dari pinggir kolam atau dermaga. Caranya adalah dengan meraih korban jika posisi korban di pinggir atau yang lebih aman dengan menggunakan alat tertentu.

b) Throw, yakni lanjutan dari reach, di mana pertolongan dilakukan dengan cara melemparkan alat terapung.

c) Row; yakni pertolongan dapat dilakukan dengan cara penolong harus mendekat kearah korban untuk meraihnya dengan menggunakan kapal kecil, kemudian penolong melakukan reach dan/atau throw. Teknik ini digunakan jika teknik pertama dan kedua tidak dapat dilakukan.

d) Go; yakni penolong bersiap untuk menolong secara langsung dikarenakan peralatan yang digunakan untuk mendekat tidak tersedia dan posisi korban jauh serta tidak memungkinkan untuk menggunakan perahu, Go merupakan pilihan terakhir yang akan dilakukan.

e) Tow/Carry; yakni teknik menolong dengan cara penolong langsung kontak dengan korban. Teknik ini paling beresiko tinggi.

Resusitasi Jantung Paru (RJP) merupakan faktor penting untuk meningkatkan peluang bertahan hidup dan pemulihan. RJP dikenal dengan masa emas yaitu tiga menit pertama terhitung sejak terhentinya detak jantung secara. Pemberian tindakan Pertolongan Pertama yang tepat akan menunda implikasi lebih buruk pada korban. Teknik atau pedoman dasar pertolongan pertama dengan metode Resutasi Jantung Paru adalah sebagai berikut.

1. Sebelum melakukan pertolongan pada korban, pastikan lingkungan sekitar aman bagi penolong maupun orang sekitar. Jangan mendekati korban bila kemungkinan bahaya lebih besar.

2. Cek kesadaran korban atau respon korban, jika tingkat kesadaran korban terlihat menurun, tepuklah bahunya agar korba sadar. Namun, jika korban tidak merespon juga maka mintalah bantuan orang sekitar untuk ikut menolong dan segera meminta bantuan medis.

3. Sambil menunggu bantuan datang, lakukan pengecekan napas korban 5-10 detik. Jika dirasakan tidak bernapas segera beri tindakan dengan melalukan Resutasi Jantung Paru. 
4. Lakukan 30 kali RJP untuk memompa jantung pada pertengahan dada (pertengahan bagian bawah tulang sternum), kecepatan minimal 100-120 kali per menit.

5. Setelah diberikan 30 kali RJP, buka jalan napas korban dengan teknik head tilt-chin lift. Tekniknya letakkan tangan di dahi korban dan tengadahkan kepala korban, lalu letakkan ujung jari anda di bawah dagu korban, kemudian angkat dagu korban. Pastikan tidak ada sisa makanan sekitar area mulut korban.

6. Kemudian berikan dua kali bantuan napas pada korban. Tutup hidung korban dengan ibu jari dan telunjuk anda. Tiup atau beri napas sekitar 1 detik untuk membuat dada korban terangkat, kemudian lanjutkan dengan tiupan berikutnya.

7. Lanjutkan 30 kali RJP dan 2 kali pemberian bantuan napas dalam 2 menit, diulang sekitar 5 kali. Lakukan pengecekan napas korban setiap 2 menit.

8. RJP bisa dihentikan saat korban memberi respon atau koran bernapas lagi. Jika penolong tidak mampu lagi memberikan pertolongan, dan tim medis sudah datang, atau sudah ada keputusan dokter maka berikan pada tim medis untuk menangani korban.

9. Jika korban bernapas setelah diberikan RJP, berikan posisi pemulihan. Tarik lengan terjauh korban melewati dadanya, dan punggung tangannya menempel pada pipi. Dengan tangan satunya, tekuk lutut kaki bagian terjauh korban. Miringkan posisi tubuh korban ke arah penolong, biarkan lutut ditekuk, kemudian tengadahkan kepala korban agar jalan napas tertahan. Pantau dan perhatikan keadaan korban hingga bantuan medis datang (Damayanti, Risa Pitriani, Kes, Yulrina Ardhiyanti, \& Kes, 2015).

\section{Aksi Sosial dan Kunjungan Wisata}

Kunjungan wisata merupakan salah satu dari rangkaian kegiatan yang diselenggarakan. Acara ini dilaksanakan untuk peserta dan panita selama dua hari terakhir sebelum penutupan kegiatan, bersamaan dengan aksi sosial. Hal ini guna mengajak mahasiwa luar pulau Lombok untuk mengmati kondisi wilayah Lombok dari tempat-tempat wisata menarik. Kunjungan wisata dan aksi sosial juga dilakukan sebagai bentuk apresiasi dan rekreasi bagi peserta pelatihan PP-SAR Air Nasional KSR-PMI Perguruan Tinggi dan Relawan Perguruan Tinggi.

Kunjungan wisata dilaksanakan selama dua har yakni pada tanggal 8-9 Mei 2018. Di antara tempat wisata yang dikunjungi adalah Museum Provinsi NTB, Islamik Center, Gunung Jae, Desa Sade, Pantai Kute/Bukit Merese dan Gili. Lebih lanjut adalah ke pusat oleh-oleh khas Lombok di Kota Mataram. Aksi Sosial dilaksanakan bersamaan dengan kunjungan wisata, di mana peserta bersama panitian membagikan pakaian layak pakai di masyarakat sekitar Wisata Gunung Jae. 


\section{SIMPULAN DAN SARAN}

Pelatihan PP-SAR Air Nasional KSR-PMI dan Relawan Perguruan Tinggi Se-Indonesia memberikan dampak yang baik bagi pengembangan skill kepalangmerahan mahasiswa. Pelatihan penanganan kebencanaan menjadi salah satu solusi penting dalam penanganan kebencanaan yang sering terjadi di Indonesia. Pelatihan Nasional ini berlangsung selama sepuluh hari dengan tahapan; 1) teori dalam kelas, 2) praktek lapangan, 3) simulasi, 4) aksi sosial, dan 5) kunjungan wisata. Materi yang disampaikan adalah manajemen kepemimpinan organisasi mahasiswa, manajemen pelatihan, radio komunikasi dan pengenalan BASARNAS, manajemen penanggul-angan bencana, pertolongan pertama, pengantar SAR air, pedoman SAR air dan metode SAR air, deven and rilis, dan akses korban dalam air. Materi tersebut disampaikan dalam kelas, praktek lapangan, dan simulasi. Keberhasilan pelatihan PP-SAR Air Nasional ini terlihat dari semangat, antusias, dan hasil simulasi yang tergolong sukses. Peserta sudah memahami teknik dan motode pelaksanaan PP-SAR Air dalam penanggulangan bencana.

\section{UCAPAN TERIMA KASIH}

Tim penulis mengucapkan terima kasih kepada: (1) Pihak Universitas Muhammadiyah Mataram atas dukungan dan pendanaanya; (2) PMI Provinsi NTB dan Kota Mataram atas dukungan, partisipasi dan fasilitasnya, (3) BASARNAS Lombok Barat atas dukungan, fasilitas dan partisipasi yang luasbiasa untuk keberlangsungan kegiatan; dan (4) KSRPMI Unit UMMAT yang telah berupaya keras sekuat tenaga menyukseskan Pelatihan Nasional ini.

\section{DAFTAR RUJUKAN}

Akbar, R., Abedi, N., Handayani, R., \& Eka, U. M. (2017). Analisis Hasil Implementasi Business Intelligence Menentukan Daerah Rawan Banjir dan Kebakaran di Indonesia. Jurnal Edukasi Dan Penelitian Informatika (JEPIN), 3(1), 65-70.

Bencana, B. N. P. (2017). Data Informasi Bencana Indonesia (DIBI). Diakses Dari Http://Bnpb. Cloud/Dibi/Laporan4.

Damayanti, I. P., Risa Pitriani, S. S. T., Kes, M., Yulrina Ardhiyanti, S. K. M., \& Kes, M. (2015). Panduan Lengkap Keterampilan Dasar Kebidanan Ii. Deepublish.

Ganthikumar, K. (2016). Indikasi dan Keterampilan Resusitasi Jantung Paru (RJP). Intisari Sains Medis, 6(1), 58-64.

Giarno, G., Dupe, Z. L., \& Mustofa, M. A. (2012). Kajian Awal Musim Hujan dan Awal Musim Kemarau di Indonesia. Jurnal Meteorologi Dan Geofisika, 13(1).

Indonesia, P. R. (2008). Peraturan Presiden Republik Indonesia Nomor 8 Tahun 2008 tentang Badan Nasional Penanggulangan Bencana. Jakarta.

Marsetio, A. P. P. W. L. (2013). Dalam Mendukung Pembangunan Indonesia Sebagai Negara Maritim Yang Tangguh. Jakarta.

Tangguh, T. T. (n.d.). Bencana.

Yulaelawati, E. (2008). Mencerdasi bencana: banjir, tanah longsor, tsunami, gempa bumi, gunung api, kebakaran. Grasindo.

Zubaidi, Z. (2018). Perencanaan Komunikasi Badan Penanggulangan Bencana Daerah (BPBD) Dalam Mengurangi Risiko Bencana Di Kota Medan. Universitas Islam Negeri Sumatera Utara. 